Author's Cases of Ovarian Grafting in the Human Subject.

I. Total number of cases recorded, 98. Indication for operation :-

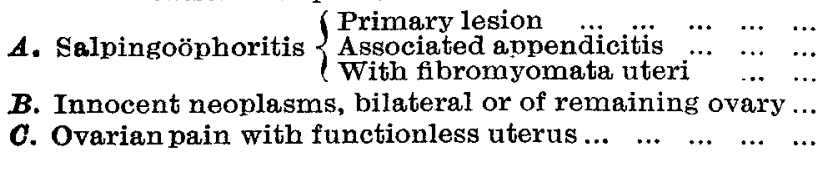

II. Total number of cases excluded, 31 .

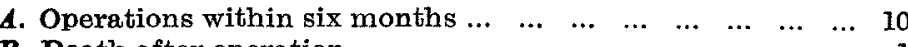

B. Death after operation

III. Total number of cases analysed, 67 .

A. Number of cases in which menstruation was possible. (a) Number of cases in which menstruation occurred

(b) Number of cases which did not menstruate and in which there was no menopausal symptom

(c) Number of cases which did not menstruate and in which there were menopausal symptoms

9

10

$B$. Number of cases in which subsequent menstruation was impossible owing to supravaginal or complete hysterectomy having been performed ... ... ...

(a) Number of cases in which menopausal symplioms did not occur

(b) Numbex of eases in which menopausal symptoms occurred

c. (a) Number of cases in which functional results were obtained

(b) Number of cases in which there was failure to obtain functional results

In one case a small Graafian follicle retention-cyst developed, and this led to continuous bleeding from the uterus. Recently I excised the cyst from the rectus muscle with the patient under the influence of a local anæsthetic. In two other cases painful swelling in the graft associated with rather profuse menstruation was observed for some months.

It is striking that in $66^{\circ} 6$ per cent. of the cases analysed menstruation should have occurred in spite of the fact that in nearly all a transverse wedge-shaped piece of the infected fundus uteri was excised. In three cases the menopausal symptoms were severe. In a very large majority of all those who complained of flushings it was, however, only by a leading question that an answer in the affirmative was obtained.

The longest period during which any of my patients has menstruated regularly is four years. As this patient is now 36 years of age she may continue to menstruate for several years. Other patients are still menstruating regularly-that is, with no longer interval than eight weeks-for over three years.

My conclusions, then, based on a fair experience, lead me to advocate very strongly the practice of ovarian grafting in suitable cases. Nevertheless, I wish again to insist that this procedure be looked upon as a measure of necessity, which can never be weighed in the balance against the preservation of the natural connexions of the normal ovary.

While endeavouring, from an examination of the information at our disposal, to assign to the ovary its place in the economy of woman, I have, I hope, made clear my belief in the sanctity of the task entrusted to those of us who deal with important living structures, knife in hand. The search after surgical knowledge is the search after better ways of assisting Nature to fulfil her purpose amid the manifold disharmonies of incomplete evolution. We have, therefore, no right wantonly to destroy. Rather must we strive to preserve intact and, if this be impossible, to foster or to substitute to the best of our ability in imitation of the original design.

The Late DR. A. D. Clark.-Arthur Desborough Clark, M.R.C.S., L.R.C.P. Edin., who died suddenly from pneumonia af,er a short illness at Hove on Oct. 19th, was one of the best-known medical practitioners in the town. Dr. Clark was 53 years of age and his death is a distinct loss to the medical profession. For 25 years he had been associated in practice with Dr. Arthur H. Dodd, and he will be missed by a large circle of patients and friends.

\section{An ghoress \\ ON}

\section{PARLIAMENT AND PUBLIC HEALTH.}

Being the Concluding Section of the Presidential

Address to the Society of Medical Officers of Health delivered on Friday, Oct. 22nd,

\section{By Lieutenant-CoLoned F. E. FREMANTLE,} O.B.E., M.P..

CONSULTING COUNTY MEDICAL OFFICER, HERTS COONTY COUNCIL.

LET us now briefly consider what the Government have done for the health of the people in the past, what they can do in the future, what they now propose to do, and how we can through Parliament shelp them to do it.

The AChievements of Government in the Past.

The early Victorian attitude in matters of health, and the far-sighted views of some of our leading statesmen may be illustrated by a delightful reply from Lord Palmerston in 1853 to a correspondent who proposed a proclamation of a national fast on account of the outbreak of cholera in 1853. The letter is from Evelyn Ashley's "Life of the Statesman." I do not suppose there is a private secretary living nowadays who would dare to write such a reply.

Sir - I am directed by Visco Viscount Palmerston to acknowledge the receipt of your letter of the 15th instant, requesting on behalf of the Presbytery of Edinburgh, to be informed whether it is proposed to appoint a day of national fast on account of the visitation of the cholera, and to state that there can be no doubt that manifestations of humble resignation to the Divine Will, and sincere acknowledgments of human unworthiness, are never more appropriate than when it has pleased Providence to afflict mankind with some severe visitation; but it does not appear to Lord Palmerston that a national fast would be suitable to the circumstances of the present moment.

The Maker of the Universe has established certain laws of nature for the planet in which we live, and the weal or woe of mankind depends upon the observance or the neglect of those laws. One of those laws connects health with the absence of those gaseous exhalations which proceed from overcrowded human beings, or from decomposing substances, whether animal or vegetable; and those same laws render sickness the almost inevitable consequence of exposure to those noxious influences. But it has at the same time pleased Providence to place it within the power of man to make such arrangements as will prevent or disperse such exhalations so as to render them harmless, and, it is the duty of man to attend to those laws of nature, and to exert the faculties which Providence has thus given to man for his own welfare.

The recent visitation of cholera, which has for the moment been mercifully checked, is an awful warning given to the people of this realm that they have too much neglected their duty in this respect, and that those persons with whom it rested to purify towns and cities, and to prevent or remove the causes of disease, have not been sufficiently active in regard to such matters. Lord Palmerston would, therefore, suggest that the best course which the people of this country can pursue to deserve that the further progress of the cholera should be stayed will be to employ the interval that will elapse between the present time and the beginning of next spring in planning and executing measures by which those portions of their towns and cities which are inhabited by the poorest classes, and which, from the nature of things, must most need purification and improvement, may be freed from those sources and causes of contagion which, if allowed to remain, will infallibly breed pestilence and be fruitful in death, in spite of all prayers and fastings of a united but inactive nation. When man has done his utmost for his own safety, then is the time to invoke the blessing of Heaven to give effect to his exertions. I am, Sir, your obedient servant

(Signed) Henry Fitzrox."

It was in accordance with such far-sighted statesmanship that the Royal Sanitary Commission was appointed in 1869, resulting in the establishment of the Local Government Board in 1872, and the passing of the Public Health Act of 1875. The main measures that ensued were those for the water-supply in 1878, for housing in 1890 , for factories in 1891, for medical inspection in schools in 1906, to mention only a few. But the 
evil of each successive new Act has been the creation in many instances of a new body of officials and local authorities under different Government departments. It was for that reason that the Ministry of Health was created last year, and has now issued a report of its flrst year's activities, showing that a beginning has been made in the process of concentrating health measures under the one Ministry.

The PRoper AIMs of a MinIsTRY OF HeALTH.

But those of us especially who have served with the Army Medical Service in the war feel that the object to be aimed at by the Ministry must be comparable to that of the Army Medical Service, which is responsible for the whole idea of health and physical efficiency, in the nation, under whatever department it may come, and not merely for the execution of certain Acts. We look to the Ministry of Health to advise the Govern ment on all health matters in which the Board of Education, the Board of Trade, the Ministry of Pensions, the Ministry of Labour, the Home Offlce are concerned-to coördinate the medical work of all departments, includ ing those of the fighting services and the India and Colonial Offices, in order to cover the whole ground. We look to them to inspire and secure coöperation between local authorities, as well as to secure unification so far as it may be possible. We look to them also to recognise the function of, and to use and help voluntary bodies, as the War Office and Admiralty recognised and valued the importance of the Red Cross during the war. For voluntary bodies initiate effort in small areas; they try experiments, and it is not until they have proved their value that the measures they suggest can be incorporated into the State system. In turn they play a most important part in arousing, maintaining, and spreading public enthusiasm for health work-an enthusiasm that is of no less importance in the main tenance of individual and family health as in ensuring a proper carrying out of their duties by the representatives of the people in local and national Govern ment. It is the privilege of medical officers of health to give a very great amount of often troublesome and exacting help to these voluntary bodies. Let us not under-rate the value of such help.

What then do the Government propose to do in the near future for the improvement of national health? It is significant that the chief activities of the Ministry of Health at the present time in the public eye are concerned with the housing of the people. Proper housing affects the social and individual habits of the nation even more than it affects their bodily health, and both directly and indirectly it is of primary importance to the national health that the shortage of housing shall be removed at as early a date as possible. But the Government are rightly concerned with the spirit as well as the matter of national life. They maintain that in general private enterprise is more effective and more suitable to the individual needs of the workers than direct production by the State. Our schemes or advice in matters of housing must always take this general desire into account. Housing, like other matters, should in the future, as in the past, be managed by private enterprise. The State should only undertake constructive housing when, where, or in so much as private enterprise fails.

Government Measures in Prospect.

There are many useful measures which the Government propose at an early date to pass into law. The Milk Bill and the Tuberculosis Regulations of the Board of Agriculture are amongst the most important. The tuberculosis measures omitted from the new Insurance Act will be awaited with great and critical eagerness. But here I would especially lay stress on the future relationship between clinical and preventive medicine and the measures suggested in the Interim Report on the Future Provision of Medical and Allied Services, by the Consultative Council, under their chairman, Lord Dawson.

By some it is imagined that the clause in the Ministry of Health (Miscellaneous Provisions) Bill now before Parliament allowing County Councils to subscribe to voluntary hospitals, or to maintain hospitals of their own, is intended as a substitute for general action on the problems raised by the Consultative Council. But this is surely a mistake. The voluntary hospitals as they at present stand fulfil a vital need. Some medical provision is immediately required for the great housing schemes now in progress. The clause in the Miscellaneous Provisions Bill is surely only a stop-gap proposal to continue the provision of medical aid until the problem can be dealt with as a whole. But in considering the future relations between clinical and preventive medicine, between public and private practice, medical officers of health will look sympathetically upon any scheme which is likely to embody in a single practical system the different branches of medical work. For there is no absolute distinction between curative and preventive practice. We hear much nowadays of specific cure of disease: may we not introduce the term " specific prevention of disease," which arises from the same train of observation and experience? Prevention of disease in the earliest stage, in out-patients' departments and in clinics, is an essential part of prevention; while, on the other hand, it is those who visit the homes of the people, whether as sanitary inspectors, nurses, health visitors, midwives, or doctors, that can save the hospitals from congestion and secure the comfort and well-being of cases when they return from hospital to their homes.

\section{Reluation of Preventive and Curative Medicine.}

To the physicians and surgeons, too, of the country, and above all in the medical schools, I would make an appeal. Their diagnosis at the bedside seldom goes further back than the causa causans of the maladygenerally nowadays a micro-organism-and a very inadequate inquiry into family history. It is submitted that this is not a final diagnosis of the disease to its roots. In teaching, in examination, in practice, it should be followed up by the student to the homes and factories. It is to the conditions of the patient's daily life and habits that the disease is due, quite as much as to the germ. Closer relationship between hospital conditions and home and factory life should be incorporated into the teaching and training of medical students and into the whole progressive thought and writings of medical science.

We whose duty it is to look at disease in the mass in the national interest, with a view to its reduction and prevention, have only an infinitesimal share in deciding and giving the proper training to the medical student. In the interest of the State we demand that this anomaly shall be drastically revised. Harley-street knows little of this aspect of medical work. It is not their fault, and they have an immense advantage over us in professional position and, in general, in academic gifts. Nor can we claim for ourselves the sole right to organise and administer the tmified system of medical provision, which the country requires. For, as the war has shown, hospitals and asylums can also provide good administrators with a modern outlook. The ultimate object must be the creation of a type, in civil life as in the Army Medical Service, of men who have an all round knowledge of clinical as well as of preventive and sanitary medicine, and are trained to administration. Meanwhile the new system must be inaugurated, and we only demand that we shall not be called on to serve under those who have not, at least, a broadminded comprehension of the main requirements and possibilities of preventive medicine in the mass.

In the same way I feel the gravest disabilities are incurred by the divorce between preventive and clinical practice, between the private practitioner and the medical officer of health. The result is shown, for instance, in the institution of tuberculosis clinics, requiring, but often failing to supply, both the knowledge and methods of the best private practitioners, and the system, organisation, and general outlook of the broad-minded medical officer of health. The future rests, to my mind, neither entirely with the whole-time service of State officials nor with the system of purely private practice subject to certain statutory obligations, but in an adequate and well-thought-out policy combining all aspects and systems of bringing help into the intimate life of the people. 
The Medical Man in Parliament.

Finally, therefore, we have to consider in what way we can assist towards the Parliamentary decisions of these problems. An individual Member of Parlia. ment obviously carries but little weight under a democratic system. The Ministry is responsible to the whole nation for its action. An individual Member brings forward a proposal, however good, backed by a society, however important; but the Minister must be assured before he acts upon it that in doing so he will have the support of the bulk of the people when they come to understand it. Medical men in the present House of Commons are 11 in number, and all but the Minister of Health have formed themselves into a Medical Committee, with Captain W. Elliot, M.C., as their secretary, and Sir Phillip Magnus and Sir Henry Craik attached to them as representing University constituencies embodying a considerable block of medical votes. This Committee meets monthly or more often as required. It receives deputations from organisations anxious to bring matters before them. Individually, they undertake to ask questions of Ministers concerned, to speak in debate on matters of importance to public health, to approach Ministers, and, so far as they can, to collect information. Dr. Addison has shown the greatest sympathy with this Committee, and we have no difficulty in securing a friendly hearing whenever required. But over and over again his reply has necessarily to be qualified by the limited amount of time and money available for Government measures and the limited proportion allotted to his department. The same applies to matters affecting the medical services of other Government departments. The chief thing required at our back is a strong public opinion throughout the country focussed on the 700 Members of Parliament, on whom Ministers could rely for support in any action they take on our suggestion, and then we should not apply in vain. Without this it is of little value to introduce a private Member's Bill or a resolution. But some good has probably been done by conferences to which all members have been invited-one, for instance, to discuss the problems connected with venereal disease, another to hear an admirable account from Sir Walter Fletcher on the work of the Medical Research Council. In such ways some effect can be produced in arousing Members to the importance of health problems to their own constituencies.

But in bringing proposals before the House and in calling for inquiries into defects it is necessary to be well briefed. Briefs have in some cases been prepared for us-e.g., by the British Dental Association or by the British Medical Association, whose parliamentary work deserves fullest recognition from this society. But there is a real need of a body on behalf of all concerned, to maintain the constant supervision over all health questions as they come, or may come, before Parliament; to focus medical opinion on such occasions, to give us opportunity for their presentation, and to arrange that each case shall be properly dealt with as it arises, with the strongest possible support behind it. There must be no division of opinion. Ministers love to ride off a difficulty by saying that "doctors differ." We must coöperate heartily with the British Medical Association, the Royal Sanitary Institute, the Royal Institute of Public Health, and all similar bodies, not forgetting the Queen Victoria's Jubilee Institute for Nurses, the National Association for Prevention of Infant Mortality, and other voluntary organisations. The Federation of Medical and Allied Societies have considered the possibility of such an undertaking. The British Medical Association have considerable machinery and have done a good deal already in this direction, especially in questions of the Services and in general medical organisation. I would submit the suggestion to this society that the time has now arrived when they should consider in what way their experience and ideals can best be made available for effecti ve use by their medical and lay sympathisers in Parliament.

Medical officers of health are the firm link between the lives of the people and their Government. The future of the country is now, more than ever, very largely in their hands.
THE MYTH OF

"ATYPICAL" ENTERIC FEVER.*

BY R. P. GARROW, M.D. ABERD., D.P.H., ASSISTANT MEDICAL OFFICER OF HEALTH, FALING ; LATE TEMPORARY CAPTAIN R.A.M.C.

THERE is, perhaps, no disease or group of diseases which has presented greater difficulties of diagnosis to clinicians and pathologists on active service than the enteric group. Anti-enteric inoculation is believed to have given rise to all sorts of "atypical, abortive, and clinically unrecognisable forms" of enteric, and has at the same time greatly increased the difficulties of laboratory diagnosis.

The conscientious diagnostician deliberately or unconsciously goes through three processes before finally arriving at a diagnosis. The first is the collection of all the evidence from every available source-clinical, bacteriological, and serological. This is a laborious process and implies daily scrutiny of the patient and, in difficult cases, repeated examinations of every region and organ of the body, together with frequent examination in the laboratory of specimens of blood, urine, and fæces. The second process is the attachment to each piece of evidence, clinical and pathological, of its correct relative weight for or against enteric -in many cases a very difficult matter. The final process is that of placing the evidence thus sorted in the balance. In the great majority of cases which are completely investigated one or other scale comes down definitely and the diagnosis is certain. The number of cases which remain in doubt should be negligible.

While enteric diagnosis has its special fascinations for clinician, bacteriologist, and serologist, nowhere in medicine is there greater necessity for close coöperation between ward and laboratory. A really satisfactory diagnosis should be supported by both elinical and pathological evidence. A bacteriological diagnosis unsupported by any clinical evidence is just as unsatisfactory as a clinical diagnosis for which no pathological support can be found.

Unfortunately the war literature of enteric fever shows little indication of such close coöperation and sifting of evidence. The tendency has been to rely on the penny-in-the-slot method of laboratory diagnosis. In many cases it is indeed obvious that the clinician has been completely dominated in the matter of diagnosis by the pathologist, neither of them apparently having been fully alive to the many pitfalls and fallacies attaching to laboratory findings and their interpretation.

\section{New "Types" of Enteric Fever.}

A direct result of this situation is the remarkable number and variety of new so-called "types" of enteric fever which have come to light during the war. The clinician has frequently been surprised and puzzled at the receipt of a report from the laboratory that enteric bacilli have been recovered from the urine or fæces, or certain agglutinins have been found in the blood-serum of a patient who presents none of the signs and symptoms of enteric, and who was never even suspected of suffering from enteric. Obsessed by the idea repeatedly instilled into him by the bacteriologist, that a bacteriological diagnosis is necessarily a correct diagnosis, he finds refuge in that blessed word "atypical." The patient is said to be a case of "atypical enteric fever." If he presents the signs and symptoms of dysentery he is a case of "enteric fever of the dysenteric type"; if he happens to be a classical example of malaria he is labelled "enteric fever of the malarial type"; if he shows the symptom-complex of trench fever he is diagnosed "enteric fever of the trench fever type" ; while if, as often happens, he shows no symptoms at all, he is, of course, a case of "enteric fever of the afebrile type."

There is no limit to the number and variety of "types" of enteric fever which may be discovered in this fashion-the process can be continued indefinitely.

* By "enteric fever" is meant bacillæinia with one or other of the ty phoid or paratyphoid organisms. 